\title{
MORPHODYNAMICS OF RIVER BHAGIRATHI AT PURBASTHALI BLOCK, BURDWAN DISTRICT, WEST BENGAL: A CONTEMPORARY PERSPECTIVE
}

\author{
Indrani Mukherjee \\ Department of Geography, Chandrapur College, Chandrapur, Burdwan, India \\ Email: indranimukherjee662@gmail.com
}

\begin{abstract}
The Bhagirathi is the principal perennial stream of the Purbasthali Block. It enters into the study area in the northwestern part, just few kilometers south of Katwa town. Analyzing the images (1973,1990,2004, 2018 and Google Earth Image) and topographical sheets(1927 and 1968-69) it has been found that the river takes a highly meandering course throughout the whole study area and leaves long loops of disused channels which have become ox-bow lakes, bils and swamps over time. The total length of the river Bhagirathi (within the study area) was reduced and the number of cut-offs has increased. These morphological aspects reveal that the river Bhagirathi is in very dynamic condition and having a tendency to shortening its course by straightening the channel. The study tries to focus on the morphological changes in the course, probability of generation of cut-offs in future.
\end{abstract}

Key words: Meander, Cut-offs, Sinuosity index, Morph dynamics

\section{Introduction}

The nature of deltaic rivers is to shift their course constantly, varying from one bank to another, popularly known as 'reach points' or 'meander belt', over centuries and even over decades. River channel shifting is a part of nature's design in forming delta lands. The height of the river plain rises with the sedimentation carried by the river flow. Gradually, the delta becomes moribund and river flows towards more low-lying areas. The same process is then repeated and new channels are formed. The left-out part becomes ox-bow Lake, bil, marshes etc. These features are nothing but the salient evidence of frequently changing river courses (Bagchi \& Mukherjee, 1978).

About Study Area

\begin{tabular}{|c|c|c|c|c|c|}
\hline Geomorphic Unit & Topography & Geology & Climate & Soil & Vegetation \\
\hline \multirow[t]{2}{*}{$\begin{array}{l}\text { Flood plain (part } \\
\text { of moribund } \\
\text { Ganga delta) }\end{array}$} & $\begin{array}{l}\text { Location: on the } \\
\text { right bank of the } \\
\text { river Bhagirathi. }\end{array}$ & \multirow[t]{2}{*}{$\begin{array}{c}\text { Composed } \\
\text { of recent } \\
\text { deposits of } \\
\text { the } \\
\text { Pleistocene } \\
\text { period. }\end{array}$} & \multirow[t]{2}{*}{$\begin{array}{l}\text { Tropical } \\
\text { monsoon } \\
\text { climatic } \\
\text { region ('Am' } \\
\text { type). }\end{array}$} & $\begin{array}{l}\text { Surface soil: } \\
\text { recent alluvial } \\
\text { formation. } \\
\text { Underlying soil: } \\
\text { older alluvium } \\
\text { formed of } \\
\text { different } \\
\text { materials. }\end{array}$ & \multirow[t]{2}{*}{$\begin{array}{c}\text { Tropical } \\
\text { moist } \\
\text { deciduous } \\
\text { Mango, } \\
\text { banana, } \\
\text { coconut, } \\
\text { palm etc. } \\
\text { are } \\
\text { common. }\end{array}$} \\
\hline & $\begin{array}{l}\text { General } \\
\text { elevation: } \\
\text { ranges from } 12 \\
\text { to } 15 \text { meters. }\end{array}$ & & & $\begin{array}{l}\text { Nature: Soil is } \\
\text { moderate to } \\
\text { strongly alkaline }\end{array}$ & \\
\hline
\end{tabular}

Source: Field visit and Survey of India Topo sheets 79 A/2 \& 79 A/6

\section{Objective of the study}

The main objectives of the study are following:

- To find out the morphological changes of the river Bhagirathi in the study area.

- To identify the areas with most oscillating channel pattern of the river Bhagirathi.

\section{Methodology}

\section{Morphometric Measures}

- $\mathrm{SI}=$ meandering length/ straight length

- Meander cut off: For the study of the cut-offs an angle is taken between the meander curves. The angle is said to be " $\theta$ ". The " $\theta$ " value when reaches $5^{\circ}$ or less and the distance 
between two tangents are $1 \mathrm{~km}$ or less the meander reaches the breaking point (Basu, 2005).

\section{Channel Change}

Topographical sheets of 1927, 1968-69, LISS-III satellite image of 2008 and 2018 are georectified and processed to identify the nature of channel oscillation and major areas of change.

\section{Analysis of Morphological Changes of the River Bhagirathi}

The Bhagirathi is the principal perennial stream of the study area. It enters into the study area in the northwestern part, just few kilometers south of Katwa town. The total length of the river within the study area is about $33.62 \mathrm{~km}$. The river takes a highly meandering course throughout the whole study area and leaves long loops of disused channels which have become ox-bow lakes, bils and swamps over time. The Bhagirathi, in its upper reaches (the reach upward the Nabadwip town) is at present a comparatively insignificant stream, but surrounding country gives evidence of the vast size which it attained when it formed the main bed of the Ganges (Gazetteers, Nadia, April 1978). Alterations are continually taking place, loops being formed, cut through and reformed throughout the whole stretch of the Bhagirathi in its seaward course. So the traces of old channels in the form of semi-circular bils or lakes are frequent along the banks.

Table 01: Some Aspects of Fluvial Morphology

\begin{tabular}{|l|c|c|c|}
\hline Morphological Properties & \multicolumn{3}{|c|}{ Bhagirathi } \\
\cline { 2 - 4 } (within study area) & 1927 & $1968-69$ & 2018 \\
\hline Actual length of river & 45.68 & 36.97 & 33.62 \\
\hline Number of meander loops & 6 & 7 & 7 \\
\hline Number of cut-offs & 4 & 5 & 7 \\
\hline
\end{tabular}

Source: Raw Data obtained from Topographical Sheets No. 79 A/2, 79 A/3, 79 A/6, 79 A/7 and 79A

Survey of India, LISS-III image of November2008 and 2018, and compiled by researcher

Table 01 depicts some important morphological aspects of the river Bhagirathi in the study area. The total length of the river Bhagirathi (within the study area) was $45.7 \mathrm{~km}$ during 1927 , which reduced to $37 \mathrm{~km}$ in 1968-69 \& now it is $33.62 \mathrm{~km}$. However, the number of cutoffs has increased from four in 1927 to seven in 2018. These morphological aspects reveal that the river Bhagirathi is in very dynamic condition and having a tendency to shortening its course by straightening the channel.

Figure 01: Sinuosity Index of the River Bhagirathi within the Study Area

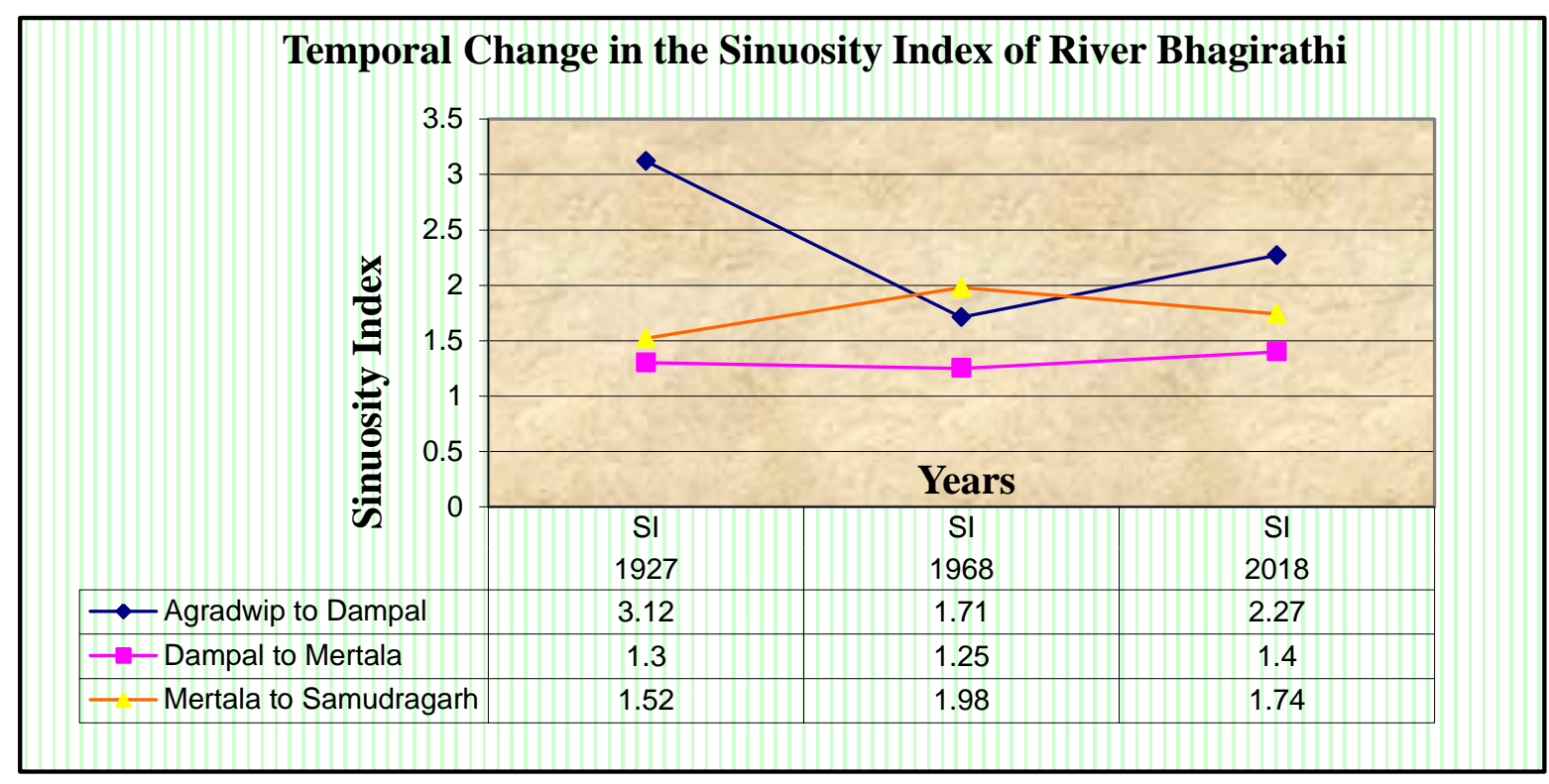

From the fig. 1 the sinuosity index of the river Bhagirathi at some particular stretches have clearly depict that the river has a winding course, due to flat gradient on which it flows and also due to the amount of sediment it is carrying. In these parts (fig.2) sinuosity ranges from 1.25 to 3.12. In 1927 the river in the Agradwip to Dampal stretch was flowing through a very 
winding or torturous course, the index was 3.12, due to which Agradwip loop (fig.1 and 2) now became a cut-off namely Chara Ganga. The sinuosity index is still very high (2.27) in this area. In Mertala to Samudragarh stretch the river is flowing through a meandering course, index ranging from 1.52 to 1.98 . The loop near the Nabadwip became very acute in 1970 to 1980 period, during the 1985 monsoon (year got from the respondents during door-to-door survey) the river by-passed the loop which now became an ox-bow lake namely Chupi bil (fig. 2). The channel deposition sometimes enhances the intensity of erosion in certain portions. In the study area, formation of mid-channel bars (near the village Nawapara, kamalnagar, Charkasthasali) and several point bars have become the sites of cultivation. In course of time, these will be stabilised making the existing channel narrower and enhances the energy level of the fluvial system. The immediate impact is severe erosion few kilometres downstream in the villages like Mertala and Majida, where the flow vectors would naturally be accelerated.

Figure 02: Oxbow Lake

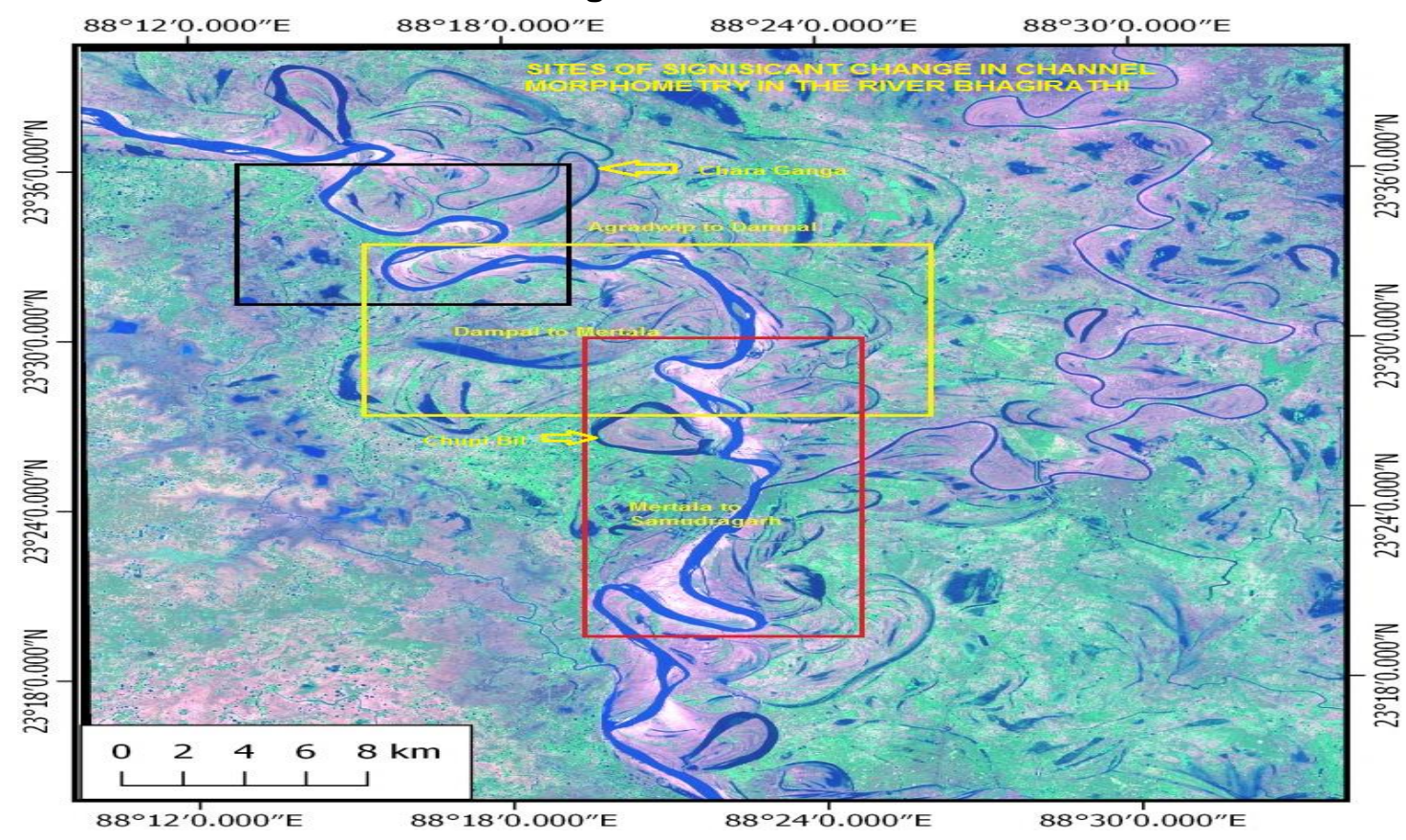

\section{Formation of Cut-offs or Bils}

The cut-offs or the bils are nothing but the former river courses, left-out as a part of dynamic fluvial condition. These cut-offs are mainly formed due to loose texture of the soil and the variation in the amount of discharge in the rivers. Continuous extension of the meander bends when riches at the breaking point, the river by-passed the meander loop with ultimate formation of cut-offs. The formation of cut-offs have led to the sudden increase in gradient because of the straitening of the channel and the increasing the hazard of river bank erosion (Basu, 1972).

For the study of the cut-offs an angle is taken between the meander curves. The angle is said to be " $\theta$ ". The value of " $\theta$ " is defined to be the angle made between two tangents in the outward direction and the tangents being drawn from such two points on the curvature of the meanders so that the angle between the tangents just shifts from inward to outwards direction. The " $\theta$ " value when reaches $5^{\circ}$ or less and the distance between two tangents are $1 \mathrm{~km}$ or less the meander reaches the breaking point. It was observed that at Purbasthali-Mayapur reach the angle made between two tangents were $4^{\circ}-5^{\circ}$ and the distance were $0.75 \mathrm{~km}$ which reached at the breaking point and cut-off had occurred namely Chupi bil (Basu,1972). In 1927 the loop near Agradwip was reached near the breaking point where the angle remained 50 and distance was $1.4 \mathrm{~km}$ (fig 3). This loop became a cut-off namely Chara Ganga about 1950s. With this idea, the author tried to find out the possibility of the formation of the cut-offs which will occur in near future in the study area. It is seen from the study of the meander curves near Patuli and Dampal that during the year 1968-69 (fig.3) for both of the curves the tangents remained parallel and divergent respectively. In 2008 (fig.5) the angle of Patuli loop became $11^{\circ}$ with distance $0.70 \mathrm{~km}$ and Dampal loop with $7^{\circ}$ angle and distance $0.65 \mathrm{~km}$. From the study of these meanders it can be assumed that both of the loops have changed in between the year 1968-69 and 2008 but they not yet reaches up to the breaking point, so they will not form a cut-off in 
very near future. The tangents remained parallel in case of other loops like Per Media and Samudragarh, so there have no chance of cut-off formation in near future (fig.6).

Figure 03

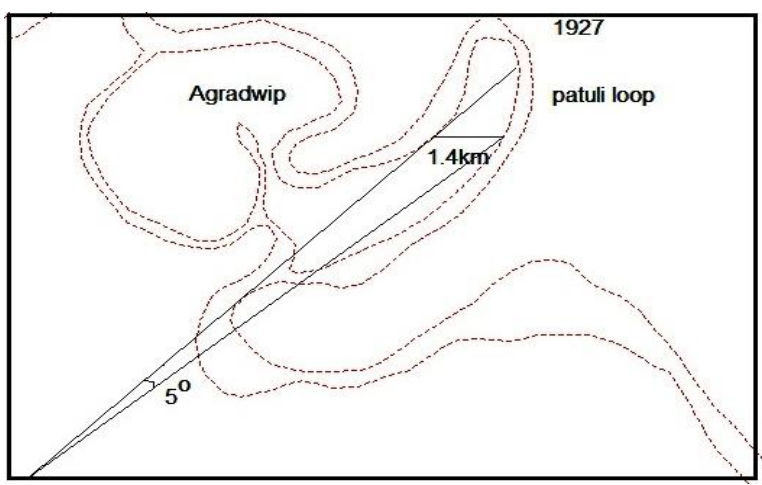

Figure 05

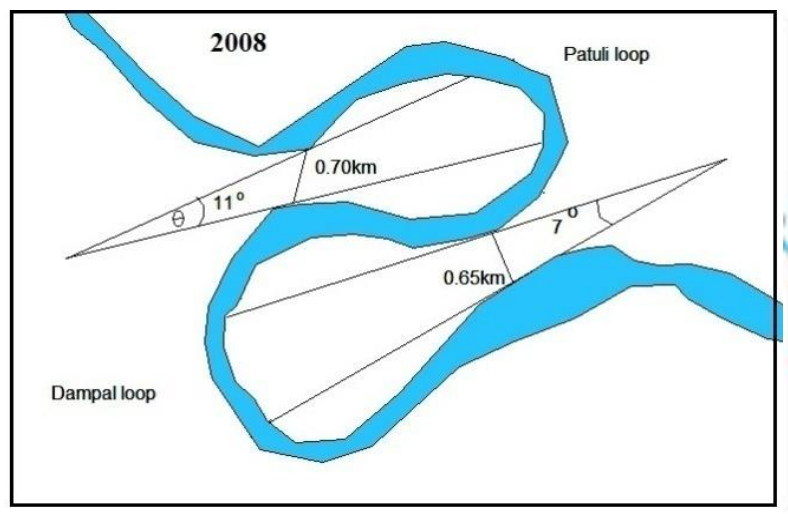

Figure 04

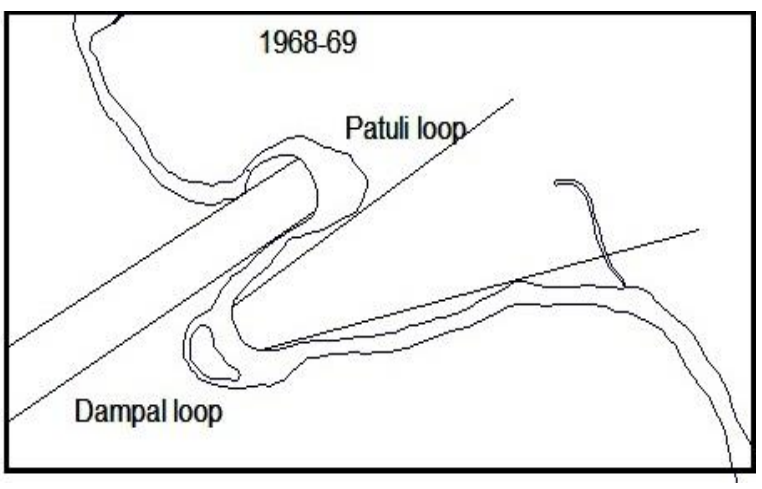

Figure 06

\section{Conclusion}

The discussion in the preceding reveals that the river Bhagirathi has an oscillating course since the past. On the basis of the records available and observations made. The river Bhagirathi is flowing in a highly meandering channel throughout the whole study area. From the fig.2 it is clear that in most of the stretches the river Bhagirathi is following in a meandering course since Rennells time to 2018. Concave banks of the river are the maximum erosion prone zones which have been observed during the field study and from the maps of the Bhagirathi floodplain. Continuous shifting of the river course threatens the railway lines and roads, settlement, schools, agricultural lands etc. The life of people in the area is highly insecure and uncertain. Bank erosion affects people, irrespective of farm sizes. Riverbank erosion causes setback for village agriculture. Along with homestead settlements, it erodes farmland, infrastructure and the communication system. The big farmers are the worst affected, followed by medium farmers, and marginal groups. The affected people lose their assets and are forced to draw on savings and often fall into further debt. Most of the environment-induced refugees turn mainly into labourers or rickshaw pullers. A large proportion of the victims remain unemployed due to lack of work opportunities. Moreover, women head many of these families. The female-headed households displaced by riverbank erosion and residing on embankments are the most deprived group. Fortunately, nowadays, social workers are focusing on these problems and also suggesting strategies of survival to these people

\section{References}

1. Bagchi, K. and Mukherjee, K. N. (1978) Diagnostic Survey of Deltaic West Bengal. Calcutta: The Project from Geography Department, Calcutta University.

2. Basu, S. R. and Chakravorty, S. C. (1972) Some considerations over the decay of the Bhagirathi drainage system. In K. G. Bagchi (Ed.), The Bhagirathi-Hooghly Basin (pp. 5977). Calcutta: R. D. Press.

3. Garrett, G. H. E. (1910, 2001) Bengal District Gazetteers, Nadia. Calcutta: Bengal Secretariat, Book Depot. 